\title{
Informaatioyhteiskunnan mummonpoluilla
}

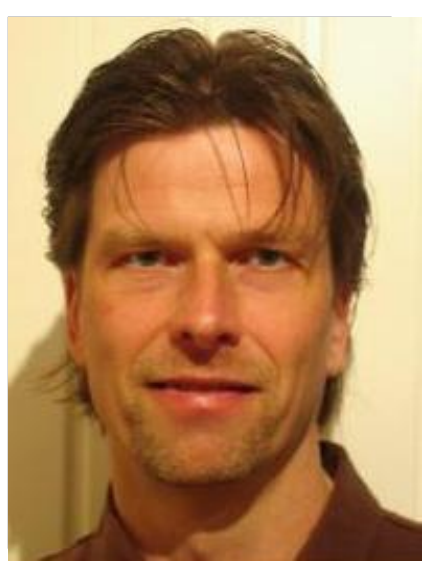

Uudesta sähköisestä mediasta, viime aikojen tarjonnan rajusta kasvusta huolimatta, ei vielä ole ollut vanhan haastajaksi. Suomalaiset ovat ovat edelleen erittäin ahkeria printtimedian, eli sanoma- ja aikakauslehtien sekä kirjojen käyttäjiä. Tulisiko maailmantilastojen kärkipaikat päivälehtien levikissä sekä kirjatuotannon volyymissa lukea Snellmanilaisen sivistysperinteen ansioksi? Vai maamme pienuudesta johtuvaksi vinoutumaksi? Kärkipaikoilta kun löytyy muitakin pieniä pohjoismaita; Norja, Tanska ja Islanti. Pimeässä Pohjolassa luetaan paljon.

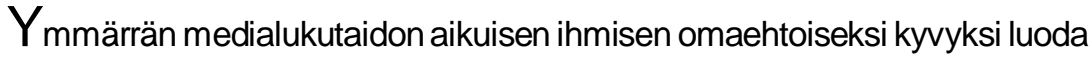
merkityksellinen suhde omaan elinympäristöönsä sekä valmiudeksi toimia yhdessä muiden kanssa hyvän ja mielekkään elämän saavuttamiseksi ja ylläpitämiseksi. Tällä tavoin määriteltynä medialukutaito ei periaatteellisella tasolla eroa niistä kyvyistä ja valmiuksista joita aikoinaan pyrittiin edistämään aikoinaan kansansivistystyön avulla. Maailma ja ihmisen elinympäristö on vain aiempaa huomattavasti pienempi, tiiviimpi ja välittyneempi. En usko enkä toivo että meistä tulee koskaan ajasta ja paikasta riippumattomia. Mutta monimuotoisetja tehokkaat yhteydet muuhun maailmaan ovat tänä päivänä mahdollisia lähes mistä tahansa.

Elämme ajassa jossa huomio kiinnittyy usein välineeseen ja sen ulkomuotoon. Mekaaninen kirjoituskone, bakeliittipuhelin, stereot tiikkipäällysteisin kauittimin sekä Suuri tietosanakirjasarja on korvautunut kannettavalla tietokoneella, matkapuhelimella, MP3-soittimella ja parilla PDF-tiedostolla. Kuljetamme kätevästi entisen kerrostalovuokrakaksion tiedonhallintainfrastruktuuurin mukanamme. Viestimme kadulla uuden teknologian ja sen käytön avulla mitä me teemme ja keitä me olemme. Informaatioteknologian mainonnassa ihmisen tarvetta itsensä toteuttamiseen ja todentamiseen hyödynnetään taitavasti. Kerro minulle mitä televisio-ohjelmia katsot, mitä radioohjelmia kuuntelet, mitä internetissä teet sekä mihin tarkoitukseen läppäriäsi ja kännykkääsi käytät niin minä sanon kuka sinä olet olevinasi!

Medialukutaidosta ja erityisesti sen kriittisistä ulottuvuuksista keskustellaan tänään lähinnä uusiin sähköisiin medioihin liittyen. Vanhat tutut ja läheiset mediat, paikalliset sanomalehdet ja paikallisradiot, mielletään ehkä liian helposti luotettaviksi tiedon lähteiksi ja välittäjiksi. Läheisyys luo turvallisuuden tunteen. Mutta jokainen oman kotipaikkakuntansa paikallislehdessä siteerattu tietää vääristymisten ja väärinymmärtämisen mahdollisuudet. Media on kuitenkin vain väline, kuin suppilo, jonka läpi vain pieni osa todellisuutta mahtuu kerralla valumaan. Myös Ilmajoki-lehden toimituksessa tehdään valintoja ja muokataan materiaalia. Paikallisten sanomalehtien 
runsaudesta ja paikallisradioiden tiheydestä huolimatta meiltä puuttuu toistaiseksi todellinen yhteisömedia. Viittaan tällä käsitteellä joukkotiedotusvälineeseen, joka toimii interaktiivisesti ja matalin kynnyksin tietyn yhteisön tai paikkakunnan asukkaiden avoimena kohtauspaikkana. Yhteisömedia on jotain muuta kuin kaupunginosalehden "Ruusuja ja risuja" -palsta tai paikallisradion "Purnausvartti". Mutta ehkä meillä menee liian hyvin. Anglosaksisen yhteisökasvatuksesta löytyy esimerkkejä siitä kuinka paikallinen media voi muuttaa muotoaan ja toimintatapaansa kylän tai kaupungin joutuessa todellisten ongelmien eteen.

Kuinka moni (aikuis)kasvatustieteen tutkija on hyödyntänyt tutkimusaineistonaan vaikkapa lehtien yleisönosastoja tai "Ruusut ja risut" -palstoja koti sekä pyrkinyt kyseisen aineiston valossa pohtimaan esimerkiksi kriittisen reflektion ja dialogisuuden eri tasoja ja muotoja? Näillä foorumeilla kun käsitellään päivittäin aikuisten kansalaisten arkielämän keskiöön sijoittuvia iloja ja murheita. Yleisönosastokirjoituksissa oma mielipide ja näkemys esitetään usein yksiselitteisesti, muttei välttämättä selkeästi argumentoiden. Politiikkaakin niissä käsitellään. Mutta kyseisenlaiset aineistot ja niiden tutkiminen taitavat olla tiedotusoppineiden reviiriä. Olen itse muutaman kerran hahmotellut kuvaa ammattitaidosta palvelualoilla kotipaikkakuntani paikallislehden "Ruusut ja risut" -kirjoitusten perusteella. Yleiskuva ei välttämättä poikkea suurestikaan ammattikasvatuksen tutkijoiden tieteellisissä teksteissään kuvaamista kvalifikaatiotypologioista ja kompetenssikartoista . Nyanssit ovat vain huomattavasti vahvemmat. Valmiiksi sähköiseen muotoon tallennettuja tutkimusaineistoja on saatavilla myös internetin keskustelupalstoilla. Nopea vierailu vaikkapa eri lomakohteisiin liittyvillä vinkki- ja keskustelupalstoilla aineistojen sai minut vakuuttuneiksi niiden rikkaudesta ja ajankohtaisuudesta. Keskusteluissa käsitellään tämän tästä sukupuolta, seksuaalisuutta, etnisyyttä ja uskontoa.

Suomalaisista koulutussukupolvista meillä aikuiskasvattajilla on vankkaa tutkimustietoa, mediasukupolviin ja -sukupuoleen vain kevyehkö sormituntuma. Kypsän iän sukupolvet katselevat televisiota, kuuntelevat radiota ja lukevat lehtiä. Toisensa he kohtaavat työpaikallaan tai kansalaisopiston kurssilla. Tulevaisuuden avaimia hallussaan pitävät sukupolvet toimivat ja kohtaavat toisensa internetissä. Yksilölliseen vastaanottoon perustuva median käyttö tullee tämän päivän nuorten aikuistuttua korvautumaan entistä selkeämmin sähköisellä medialla kohtauspaikkana ja yhteisöllisen tiedon tuottamisen välineenä. Nähtäväksi jää miten työpaikan kahvihuone ja kansalaisopiston keramiikkapaja uusiokäytetään. Lähetetäänkö kansalaisopistojen innokkaimmat käyttäjät mummopolkujen kautta netin chattipalstoille? Mummonpoluista tarkemmin kansalaisverkkoja käsittelevässä artikkelissa. 